\title{
О НЕОБХОДИМОСТИ РАЗРАБОТКИ МЕР АДМИНИСТРАТИВНОЙ И УГОЛОВНОЙ ОТВЕТСТВЕННОСТИ К ЛИЦАМ, РАЗМЕЩАЮЩИМ В СЕТИ «ИНТЕРНЕТ» ПОРОЧАЩУЮ ГРАЖДАН ИНФОРМАЦИЮ
}

Аннотация. Авторы подробно рассматривают такие аспекты темы как обеспечение адекватных форм противодействия распространению запрещенной законом информации, в том числе порочащей информации в сети "Интернет». Данное явление стало серьезной проблемой практически для каждого и несет реальную угрозу информационной безопасности любой личности. Достижение целей информационной безопасности зачастую предполагает и определённые ограничения, накладываемые государством на информационный обмен. Имеющихся правовых средств для борьбы с распространением порочащей информации в сети "Интернет" явно не достаточно, т.к. структура и идеология существования социальных сетей делают имеющиеся правовые процедуры малоэффективными. В процессе исследования также были использованы методы анализа, синтеза, моделирования, прогнозирования, статистический, социологический, принцип единства предмета и метода изучения, принцип научной корректности. Основным выводом проведенного исследования является тезис о необходимости разработки системы мер административной и уголовной ответственности к лицам, которые размещают и распространяют в информационнотелекоммуникационной сети «Интернет» информацию, порочащую граждан. Такая мера не должна нести угрозу информационным правам и свободам иных субъектов деятельности в российском сегменте «Интернет» и требуется для повышения эффрективности противодействия любым антиморальным, или иным незаконным проявлениям.

Ключевые слова: Информация, Информационная безопасность, сеть "Интернет", порочащая информация, противодействие, уголовное право, административное право, ответственность, социальные сети, личная ответственность.

Review. The authors discuss the provision of appropriate counteractions to the proliferation of the data prohibited by the law, including defamation, on the Internet. This phenomenon has become a serious problem and an information safety threat for almost everyone. Information safety often presupposes certain limits which the state imposes on the information exchange. The existing legal measures for preventing Internet defamation are not enough, since the structure and the ideology of social networks make the existing legal procedures ineffective. The authors apply the methods of analysis, synthesis, modeling, forecasting, the statistical and sociological methods, and the principles of integrity of a subject and scientific correctness. The main conclusion of the research is the thesis about the necessity to develop the system of measures of administrative and criminal liability for Internet defamation. Such measures shouldn't threaten information rights and freedoms of other subjects of activity in the Russian segment of the Internet, and should be only used for the increase of efficiency of prevention of any amoral or illegal actions.

Keywords: liability, administrative law, criminal law, counteraction, defamation, Internet, Information safety, information, social networks, personal responsibility.

$\mathrm{B}$ современно мире, где каждый день генерируется огромный поток сообщений, общество все более зависимо от информации. Однако, не всякая информация полезна для потребителей, поэтому основным направлением развития го- сударственной политики Российской Федерации в информационно-телекоммуникационной сети «Интернет» является организация контрпропагандистской работы в виртуальном пространстве, распространение установок неприятия экстре- 
мистской идеологии, формирование устойчивого молодежного имиджа, ориентированного на ценностные приоритеты современного российского общества, которая проводится с участием институтов гражданского общества и интернет-провайдеров. Разрабатываемые и принятые нормативные правовые акты в этой сфере преследуют цель обеспечения информационной безопасности государства, граждан и субъектов хозяйственной деятельности.

В Доктрине информационной безопасности Российской Федерации, утвержденной Президентом РФ 09.09.2000 г. N Пр-1895, интересы личности в информационной сфере рассматриваются при реализации следующих конституционных прав человека и гражданина: на доступ к информации, на использование информации в интересах осуществления не запрещенной законом деятельности, физического, духовного и интеллектуального развития, в защите информации, обеспечивающей личную безопасность.

Требования к информации, размещаемой на сайтах, содержатся, в Федеральном законе от 27 июля 2006 г. N 149-Ф3 «Об информации, информационных технологиях и о защите информации», а также в Федеральных законах от 29 декабря 2010 г. $\mathrm{N} 436-Ф 3$ «0 защите детей от информации, причиняющей вред их здоровью и развитию», от 25 июля 2002 г. N 114-Ф3 «0 противодействии экстремистской деятельности», от 29 декабря 2006 г. N 244-Ф3 «0 государственном регулировании деятельности по организации и проведению азартных игр и о внесении изменений в некоторые законодательные акты Российской Федерации» и других.

Ответственность за правонарушения, связанные с несоблюдением требований к информационному наполнению сайта, закрепляется в гражданском, административном и уголовном законодательстве. Однако применение ответственности за их нарушение связано со значительными затруднениями, о чем свидетельствует то, что социальные сети активно используются для распространения противоправного контента. Поэтому обеспечение адекватных форм противодействия распространению запрещенной законом информации, в том числе и в социальных сетях, стало насущной потребностью.

Все чаще социальные сети становятся тем пространством, где получают возможность распространять информацию субъекты, не признающие никаких социальных норм. Это грубые злые, люди, полностью лишенные любых моральных принципов, духовно нищие, их публикации, как правило, это - конгломерат самых низменные инстинктов.

К сожалению, правоохранительными органами фиксируется все больше случаев, когда груп- повые оргии с изнасилованием выкладываются в сети Интернет. Так недавно нашумевшее происшествие на дискотеке первокурсников Московского автодорожного института, когда группой подростков была изнасилована семнадцатилетняя девушка и видео было опубликовано в социальной сети [1], а так же можно вспомнить дело об изнасиловании в Новосибирске - фото и видео изнасилования преступники без цензуры выложили в социальные сети[2] или недавнюю историю в Пскове, где подростки опубликовали фото своих издевательств над голой школьницей[3].

И.Л. Бачило, на заседании Секции права Центрального дома ученых РАН отметила, что в настоящее время существует проблема разрыва между развитием информационных технологий, с одной стороны, и держателями и пользователями информационных ресурсов - с другой. Так, обнаруживается разрыв между психологией и идеологией разработчиков информационных технологий и теми, кто хочет получить эту информацию[4].

Распространение порочащей информации в сети «Интернет» стало серьезной проблемой практически для каждого из нас и несет реальную угрозу информационной безопасности любой личности. Как заметил И.М. Рассолов, чтобы опорочить человека, заинтересованному субъекту (лицу) достаточно разместить соответствующие сведения на каком-либо посещаемом сайте в Интернете, и их будет обсуждать неограниченный круг лиц, на них будут ссылаться как на источник информации. Таким образом, распространяется информация, дискредитирующая простых граждан, участников интернет-отношений, известных государственных деятелей, конкурентов в избирательных кампаниях разных уровней и т. д.[5]

Мы позволим себе не согласится с И.М. Рассоловым, что правовое регулирование ответственности за распространение информации, порочащей честь и достоинство, хорошо разработано в России[5].

Имеющихся правовых средств для борьбы с этим негативным влиянием явно не достаточно, так в соответствие со статьей 15.1 Федеральнго закона от 27 июля 2006 г. N 149-ФЗ «Об информации, информационных технологиях и о защите информации» может быть ограничен доступ к сайтам в сети «Интернет», содержащим информацию, распространение которой в Российской Федерации запрещено, и пунктом 5 ст. 152 ГК РФ, если сведения, порочащие честь, достоинство или деловую репутацию гражданина, оказались после их распространения доступными в Интернете, гражданин вправе требовать удаления соответствующей информации. Однако структура и идеология существования социальных сетей делают такие процедуры малоэффективной, так однажды помещенная в сеть информация, пу- 


\section{Административное и муниципальное право 11 (95) 2015}

тем многократного копирования и тиражирования по личным страницам пользователей соцсетей, а так же размещения на различных файлообменных серверах вне юрисдикции Российской Федерации и закрытых сетевых пространствах типа анонимной распределенной сети TOR, не позволяют полностью удалить из виртуального пространства порочащую информацию.

Проведенный анализ показал, что даже по прошествии некоторого времени приложив определенные усилия можно было получить доступ к видеоматериалам, запечатлевших вышеуказанные преступные деяния. А травля жертв этих преступлений в различных сетевых сообществах продолжается на момент написания данной работы (ноябрь 2015 г.).

Достижение целей информационной безопасности зачастую предполагает и определённые ограничения, накладываемые государством на информационный обмен. Мировой опыт свидетельствует о целесообразности такого вмешательства в глобальную сеть для пресечения распространения в ней негативного контента. Насущной задачей стало преодоление дисбаланса между реальной свободой Интернет-общения и тем негативным представлением об этом, которое базируется на тезисе «Интернет - это зона полной свободы и невмешательства государства».

По мнению М.А. Лапиной и Б.С. Николаенко одними из наиболее важных направлений деятельности государства в информационной сфере являются выработка и реализация политики государства в отношении обеспечения безопасности информации для общества, создание нормативной правовой базы для регулирования отношений при публикации материалов через информационные каналы, а также наделение полномочий соответствующих органов исполнительной власти по осуществлению контроля за информационными ресурсами телекоммуникационных сетей[6].

На наш взгляд, в настоящее время назрела необходимость усилить ответственность за размеще- ние и распространение (тиражирование) порочащих материалов в сети Интернет. Так же требуют устранения правовые пробелы, оказывающие воздействие на формировании идеологии информационного взаимодействия и формирования контента как непосредственно у владельцев платформ, онлайн-сервисов или веб-сайтов, предназначенные для построения, отражения и организации социальных взаимоотношений в сети «Интернет», а так же у владельцев личных страниц в социальной сети, по отношению к диффамационным материалам.

Мы согласны с тезисом о том, что чрезмерные попытки ограничить информационный обмен путем введения в административном порядке процедур управления, блокирования и определенных ограничений на информационные ресурсы, может привести к переходу от эффективного регулирования Интернет-пространства к его тотальному контролю властью и как следствие к преследованию любых Интернет-ресурсов[7]. И считаем, что реальный заслон распространению порочащих материалов можно поставить путем именно правового воздействия на субъектов, распространяющих такую информацию.

На наш взгляд, административно-правовая, а так же по необходимости уголовно-правовая охрана всех аспектов информационной безопасности личности является наиболее действенной и эффективной.

Таким образом, можно сделать вывод, что необходимо разработать систему мер административной и уголовной ответственности к лицам, которые размещают и распространяют в информационно-телекоммуникационной сети «Интернет» информацию, порочащую граждан. Такая мера не должна нести угрозу информационным правам и свободам иных субъектов деятельности в российском сегменте «Интернет» и требуется для повышения эффективности противодействия любым антиморальным, или иным незаконным проявлениям.

\section{Библиография:}

1. В МАДИ расследуют групповое изнасилование 17-летней студентки URL: http://www.ntv.ru/novosti/1543077/

2. Любимова А. Приговор по делу «солевой» вынесли в Новосибирске URL: http://sibkray.ru/news/1/876559/

3. На псковских подростков завели уголовное дело за издевательства над школьницей URL: http://lenta.ru/ news/2015/09/29/violence/

4. Залоило М.В., Власова Н.В. Социальные интернет-сети: правовые аспекты // Журнал российского права. 2014. № 5

5. Рассолов И.М. Правовые проблемы ответственности за распространение по Интернету сведений, порочащих честь, достоинство и деловую репутацию // Представительная власть. - 2007. - Спецвыпуск (М9 73).

6. Лапина М.А., Николаенко Б.С. Информационная функция государства в сети Интернет // Информационное право. 2013. № 4. С. 11-15.

7. Остроушко А.В. Актуальные вопросы ограничения доступа к сайтам в сети «Интернет» с информацией, распространяемой с нарушением законодательства РФ // Актуальные проблемы информационного права / под. ред. И.Л. Бачило и М.А. Лапиной. М.: Юстиция, 2016. 
8. Букалерова Л.А., Остроушко А.В. Специфика уголовной, административной, гражданско-правовой ответственности за информационные правонарушения в системе публичного управления // NB: Административное право и практика администрирования. - 2015. - 1. - С. 81 - 94. DOI: 10.7256/2306-9945.2015.1.14109. URL: http://www.enotabene.ru/al/article_14109.html

\section{References (transliterated):}

1. V MADI rassleduyut gruppovoe iznasilovanie 17-letnei studentki URL: http://www.ntv.ru/novosti/1543077/

2. Lyubimova A. Prigovor po delu «solevoi» vynesli v Novosibirske URL: http://sibkray.ru/news/1/876559/

3. Na pskovskikh podrostkov zaveli ugolovnoe delo za izdevatel'stva nad shkol'nitsei URL: http://lenta.ru/ news/2015/09/29/violence/

4. Zaloilo M.V., Vlasova N.V. Sotsial'nye internet-seti: pravovye aspekty // Zhurnal rossiiskogo prava. 2014. № 5

5. Rassolov I.M. Pravovye problemy otvetstvennosti za rasprostranenie po Internetu svedenii, porochashchikh chest', dostoinstvo i delovuyu reputatsiyu // Predstavitel'naya vlast'. - 2007. - Spetsvypusk (M9 73).

6. Lapina M.A., Nikolaenko B.S. Informatsionnaya funktsiya gosudarstva v seti Internet // Informatsionnoe pravo. 2013. № 4. S. 11-15.

7. Ostroushko A.V. Aktual'nye voprosy ogranicheniya dostupa k saitam v seti «Internet» s informatsiei, rasprostranyaemoi s narusheniem zakonodatel'stva RF // Aktual'nye problemy informatsionnogo prava / pod. red. I.L. Bachilo i M.A. Lapinoi. M.: Yustitsiya, 2016.

8. Bukalerova L.A., Ostroushko A.V. Spetsifika ugolovnoi, administrativnoi, grazhdansko-pravovoi otvetstvennosti za informatsionnye pravonarusheniya $\mathrm{v}$ sisteme publichnogo upravleniya // NB: Administrativnoe pravo i praktika administrirovaniya. - 2015. - 1. - C. 81 - 94. DOI: 10.7256/2306-9945.2015.1.14109. URL: http://www.e-notabene.ru/ al/article_14109.html 